\title{
POLIMORFISME VARIAN T-344C GEN FAKTOR TRANSKRIPSI STORKHEAD BOX 1 (STOX1) SEBAGAI KANDIDAT BIOMARKER PREEKLAMPSIA
}

\author{
Mukhamad Nooryanto*, Kusnarman Keman*, Erry Gumilar Dahlan*, Anin Indriani* $\bowtie$
}

\begin{abstract}
Abstrak
Insiden preeklampsia dan eklamsia dapat menyebabkan kematian pada ibu hamil, dan pada wanita dengan riwayat keluarga menderita preeklampsia lebih berisiko dibandingkan dengan wanita tanpa riwayat keluarga dengan preeklampsia. Penelitian terdahulu mengindikasikan bahwa gen Storkhead Box 1 (STOX1) merupakan salah satu penyebab preeklampsia. Penelitian ini bertujuan untuk menganalisis polimorfisme varian T-344C gen STOX1 dalam kromosom 10q22 sebagai kandidat biomarker preeklampsia. Penelitian dilaksanakan secara kuantitatif observasional dengan desain cross-sectional pada sampel darah wanita hamil dengan preeklampsia (kelompok kasus) dan darah wanita yang hamil normal (kelompok kontrol) di kamar bersalin SMF Obstetri dan Ginekologi RSUD Dr. Saiful Anwar Malang. Sampel darah vena diambil dari 25 wanita hamil dengan preeklampsia dan 25 wanita hamil normal yang memenuhi kriteria penelitian dan dilakukan ekstraksi DNA. Identifikasi gen STOX1 dilakukan dengan metode PCR dengan forward primer adalah 5'-TGGGTGTGAA-3' dan reversed primer 5'-TTGGAGCGTTTGATGAAACA-3' (First Base, USA) dan analisis varian T-344C dengan RFLP menggunakan enzim Haelll. Data dianalisis secara statistik dengan aplikasi SPSS. Amplifikasi gen STOX1 dengan PCR pada kelompok preeklamsia dan kontrol menunjukkan produk sebesar $639 \mathrm{bp}$. Analisis polimorfisme varian T-344C pada kelompok normal memiliki frekuensi TT $64 \%$, TC $28 \%$, dan CC $8 \%$. Sementara pada kelompok preklampsia frekuensi TT $72 \%$, TC $28 \%$ )dan tidak ditemukan adanya polimorfisme CC yang bersifat homozigot. Tidak ditemukan hubungan yang signifikan antara polimorfisme varian T-344C gen STOX1 dengan preeklampsia (Uji Mann Whitney $p=$ $0,668>0,05)$. Kesimpulanya, secara teknis pemeriksaan varian T-344C gen STOX1 dapat digunakan sebagai kandidat biomarker preeklamsia, namun secara spesifik tidak sensitif untuk menjelaskan adanya hubungan antara polimorfisme varian T-344C gen STOX1 dengan preeklampsia.
\end{abstract}

Kata kunci : biomarker, gen STOX1, polimorfisme. preeklampsia, varian T-344C

\section{POLYMORPHISM OF T-344C VARIANT TRANSCRIPTION FACTORS STORKHEAD BOX 1 GENE (STOX1) AS A CANDIDATE OF BIOMARKER OF PREECLAMPSIA}

\begin{abstract}
The incidence of preeclampsia and eclampsia can cause death in pregnant women, and women with a family history of preeclampsia are more at risk than women without a family history of preeclampsia. Previous studies have indicated that the Storkhead Box 1 (STOX1) gene is one of the causes of preeclampsia. This study aims to analyse the polymorphism of the T-344C variant of the STOX1 gene on chromosome $10 \mathrm{q} 22$ as a biomarker candidate of preeclampsia. The study was conducted in a quantitative observational study with a cross-sectional design on blood samples of pregnant women with preeclampsia (case group) and normal pregnant women (control group) in the delivery room at SMF Obstetrics and Gynaecology Dr. Saiful Anwar Public Hospital Malang. Venous blood samples were taken from 25 pregnant women with preeclampsia and 25 normal pregnant women who fulfilled the study criteria and carried out DNA extraction. The identification of the STOX1 gene was carried out by the PCR method with the forward primer $5^{2}$ TGGGTGTGAA-3 'and the reversed primer 5'-TTGGAGCGTTTGATGAAACA-3' (First Base, USA) and RFLP using the Haelll enzyme to analyse T-344C variant. Data were analysed statistically by SPSS software. Amplification of the STOX1 gene by PCR in preeclampsia and normal groups showed a product of $639 \mathrm{bp}$. Polymorphism of the T-344C variant analysis in the normal group showed TT frequency $64 \%$, TC $28 \%$, and CC $8 \%$. Meanwhile, in the preeclampsia group, the frequency of TT $72 \%$, TC $28 \%$, and no CC polymorphism that was homozygous. There was no significant correlation between T-344C variant STOX1 gene polymorphisms and preeclampsia (Mann Whitney test $p=0.668>0.05$ ). In conclusion, technically examining the T-344C variant of the STOX1 gene can be used as a candidate of biomarker of preeclampsia, but it is specifically insensitive to explain the relationship between polymorphisms of the T-344C variant of the STOX1 gene and preeclampsia.
\end{abstract}

Keywords: biomarker, polimorphism. Preeclampsia, STOX1 gene, T-344C variant

* Departemen Obstetri dan Ginekologi, Fakultas Kedokteran, Universitas Brawijaya

E-mail: draninspog@ub.ac.id 


\section{Pendahuluan}

Preeklampsia dan eklamsia menyebabkan kematian lebih dari 50.000 ibu hamil setiap tahunnya di dunia. ${ }^{1}$ Di Rumah Sakit Cipto Mangunkusumo Jakarta, ditemukan 400 -500/4000-5000 kasus pertahun. Etiologi dan patofisiologi preeklampsia dan eklamsia diperkirakan akibat gangguan plasentasi pada stadium awal kehamilan akibat kombinasi dari faktor maternal dan lingkungan yang menyebabkan inflamasi secara sistemik, disfungsi endotel dan manifestasi klinik yang terjadi pada maternal. ${ }^{2}$

Faktor kerentanan genetik dari kedua orang tua diketahui sebagai penyebab preeklampsia dan eklamsia. Hal ini berdasar pada insidens preeklampsia dan eklamsia pada wanita dengan riwayat keluarga menderita preeklampsia adalah tiga kali lebih tinggi dibandingkan dengan wanita tanpa riwayat keluarga dengan preeklampsia. ${ }^{3}$ Kendati beberapa lokus genetik telah dipetakan, hanya sedikit gen kandidat penyebab preeklampsia dan eklamsia yang telah diidentifikasikan sejauh ini. ${ }^{4}$

Salah satu gen penyebab preeklampsia dan eklamsia adalah gen Storkhead Box 1 (STOX1) yang terdapat dalam kromosom 10q22. Penelitian yang dilakukan oleh Lachmeijer et al. (2001) yang melakukan studi analisis sib-pairs pada sebuah keluarga menemukan kecenderungan adanya hubungan preeklampsia dengan kromosom 2p13, 2p22 dan 9p13.5 Lokus kromosom 10q22 telah diteliti merupakan suatu alel gen yang menunjukkan hubungan pada saudara yang mengalami preeklampsia. Alel tersebut hanya mencakup alel maternal, namun tidak alel paternal. van Dijk et al. (2005) menemukan adanya lima mutasi missense berbeda pada gen STOX1 yang terdapat pada kromosom 10q22. Kelima mutasi ini diidentifikasikan sebagai penyebab preeklampsia pada suatu keluarga, bersifat identik pada saudara perempuan yang mengalami dan mengikuti garis maternal 6,7

Gen STOX1 berpengaruh pada proses transisi dari nonivasif ke trofoblas yang invasif yang merupakan sentral perkembangan plasenta normal sehingga dapat dijadikan sebagai faktor penentu preeklampsia. Namun, Ignasias-Palatas et al. (2007) mengemukakan bahwa ekspresi STOX1 sangat rendah pada plasenta dan sel trofoblas.8,9 Penelitian lain membuktikan bahwa STOX1 mampu beperan langsung pada gen target spesifik dan menginduksi transkripsi protein yang terjadi pada preeklampsia. Studi sebelumnya yang membandingkan ekspresi gen pada perkembangan awal plasenta (gravida 10-12 minggu) pada wanita dengan preeklampsia dengan wanita dengan kehamilan normal, menunjukkan STOX1 berperan pada wanita preeklampsia. Hal ini membuktikan disregulasi STOX1 terjadi dari awal pada preeklampsia. ${ }^{10}$

Selain gen STOX1, beberapa kandidat gen lainnya adalah CYP11B2, eNOS, dan $A C E$ yang dapat digunakan untuk memprediksi komplikasi seperti hipertensi dan preeklampsia. ${ }^{11}$ Penelitian Devendran et al. (2015) pada wanita etnis India dengan kehamilan sehat menunjukkan bahwa frekuensi polimorfisme alel minor $-344 C>T$ pada gen CYP11B2 diketahui lebih rendah secara signifikan dibandingkan dengan populasi Jepang dan Afrika ( $p=0,0001)$. Gen CYP11B2 berfungsi pada regulasi aktivitas aldosteron dan sistem kardiovaskuler. ${ }^{12}$ Pada gen ini diketahui ada tiga polimorfisme yang utama. Salah satunya adalah mutasi C-344T pada daerah promoter gen yang terkait dengan tekanan darah tinggi dan stroke ischemic yang ditemukan pada populasi China. ${ }^{13}$

Oleh karena itu, suatu metode identifikasi dini pasien preeklampsia pada trimester pertama sebelum ditemukan gejala mutlak diperlukan. Dengan identifikasi dini penderita preeklampsia maka dimungkinkan untuk melakukan pemantauan penderita 
dengan hati-hati dan memberikan pengobatan segera setelah gejala pertama terjadi atau bahkan sebelumnya. ${ }^{14}$ Tujuan dari penelitian ini adalah untuk menentukan polimorfisme varian C-344T gen STOX1 kromosom 10q22 sebagai kandidat biomarker dalam mendeteksi pasien preeklampsia secara dini, serta untuk mengetahui apakah polimorfisme tersebut terkait dengan kejadian preeklamsia.

\section{Bahan dan Metode}

\section{Rancangan Penelitian}

Penelitian ini dilaksanakan secara kuantitatif observasional dengan desain cross -sectional. Penelitian eksplorasi laboratorium ini menggunakan sampel darah vena yang diambil dari kelompok wanita hamil dengan preeklampsia (kelompok kasus) dan kelompok wanita yang hamil normal (kelompok kontrol).

\section{Populasi dan Sampel Penelitian}

Populasi dalam penelitian ini adalah seluruh wanita hamil yang melahirkan di kamar bersalin RSUD Dr. Saiful Anwar Malang yang bersedia mengikuti penelitian ini dan memenuhi kriteria inklusi yaitu: hamil trimester ke-3 (>34 minggu), hamil kurang trimester ke-3 (<34 minggu), primigravida, hamil dengan preeklampsia (kelompok kasus), hamil normal (kelompok kontrol). Pasien wanita hamil yang menderita penyakit infeksi, hipertensi kronis, dan diabetes mellitus dikeluarkan dari penelitian ini.

\section{Metode Sampling dan Besar Sampel}

Pengambilan sampel penelitian ini di lakukan secara kuota sampling berdasarkan kurun waktu sejak Pebruari sampai April 2013. Besar sampel pada kelompok kasus dan kelompok kontrol pada penelitian ini masing-masing sebanyak 25 sampel.

\section{Variabel Penelitian}

Variabel bebas pada penelitian ini adalah wanita hamil dengan preeklampsia dan wanita hamil normal. Variabel terikat adalah gen STOX1.

\section{Batasan Operasional Variabel Penelitian}

Preeklampsia didefinisikan sebagai peningkatan tekanan darah $\geq 140 / 90 \mathrm{mmHg}$ pada kehamilan di atas 20 minggu dengan disertai proteinuria $(>300 \mathrm{mg} / 24$ jam atau dipstick +1) yang disebabkan oleh kehamilannya dengan gejala-gejalanya segera menghilang setelah persalinan. Usia kehamilan adalah lamanya suatu kehamilan yang dihitung dari hari pertama haid terakhir menggunakan rumus Naegele. Normal adalah dengan kriteria tekanan darah $<140 / 90$ dan tidak didapatkan proteinuria pada pemeriksaan urinalysis.

\section{Ekstraksi DNA}

DNA total diekstrak dari sampel darah vena menggunakan metode salting out. Sebanyak $200 \mu \mathrm{l}$ sampel darah ditambah 600 $\mu l$ larutan potassium acetat untuk melisiskan eritrosit, lalu disentrifus suhu $4{ }^{\circ} \mathrm{C}$ dengan kecepatan maksimum selama 3 menit. Kemudian pelet limfosit dilisiskan dengan SDS-proteinase $\mathrm{K}$, diikuti dengan penambahan sodium klorida $6 \mathrm{M}$. Campuran tersebut kemudian disentrifus pada kecepatan $14.000 \mathrm{rpm}$ selama 3 menit untuk mempresipitasi protein. Supernatan dipindahkan ke dalam tabung lain dan ditambahkan $600 \mu \mathrm{l}$ ethanol absolut dingin untuk mempresipitasi DNA dan disentrifus pada kecepatan 14.000 rpm selama 1 menit. Pelet DNA dicuci dengan $500 \mu \mathrm{EtOH} 70 \%$ dan disentrifus kembali. Sampel DNA ditambah $100 \mu$ buffer TE steril pH 7,6 dan disimpan pada $-20^{\circ} \mathrm{C}$.

Reaksi Polymerase Chain Reaction (PCR) Gen STOX1

Proses PCR dilakukan dengan mencampurkan bahan PCR dengan DNA template hingga volume akhir $50 \mu \mathrm{L}$. 
Komponen bahan adalah $5 \mu \mathrm{L}$ 10x MgCl-2free PCR buffer, DNA template (konsentrasi akhir $200 \mathrm{pg} / \mu \mathrm{L}), 1 \mu \mathrm{L} 0,5 \mu \mathrm{M}$ primer forward (5'-TGGGTGTGAA-3') dan $1 \mu \mathrm{L} 0,5 \mu \mathrm{M}$ primer reverse (5 ' TTGGAGCGTTTGATGAAACA-3'), 0,8 $\mu \mathrm{L}$ 0,2 mM dNTP mix, 0,5 $\mu \mathrm{L}$ 2.5U Taq polymerase, $5 \mu \mathrm{L} 5 \%$ dimethyl sulfoxide (DMSO) $10 \mu \mathrm{L}$ 10\% gliserol, $1 \mu \mathrm{L}$ 1\% Perfect Match Polymerase Enchancer (PMPE), dan ddH2O. Proses amplifikasi gen STOX1 dilakukan pada sekuen reaksi berikut: denaturasi pada suhu $98^{\circ} \mathrm{C} 10$ detik, diikuti 24 siklus yang dimulai dengan denaturasi pada suhu $94{ }^{\circ} \mathrm{C} 10$ detik, annealing suhu $67^{\circ} \mathrm{C} 30$ detik, extension suhu $72{ }^{\circ} \mathrm{C} 30$ detik, elongation suhu $72{ }^{\circ} \mathrm{C} 5$ menit. Produk PCR lalu dievaluasi dengan elektroforesis agarosa $1 \%$.

\section{Reaksi Restriction Fragment Length Polymorphism (RFLP) Varian C-344T Gen STOX1}

Proses RFLP dilakukan dengan mencampurkan DNA hasil amplifikasi dengan PCR yaitu sebanyak $3 \mu \mathrm{L}(5 \mathrm{pg} / \mathrm{mL})$ dengan 1 $\mu \mathrm{L}$ enzim Haell dan $1 \mu \mathrm{L}$ buffer enzim $2 x$, kemudian ditambahkan nuclease-free water $15 \mu \mathrm{L}$. Campuran tersebut diinkubasi pada suhu $37{ }^{\circ} \mathrm{C} 1$ jam. Reaksi enzim dinon- aktifkan dengan inkubasi tabung pada suhu $80{ }^{\circ} \mathrm{C} 15$ menit. Hasil RFLP dievaluasi dengan elektroforesis agarosa $5 \%$.

\section{Analisis Data}

Data varian C-344T gen STOX1 pada wanita hamil normal dan wanita hamil dengan preeklampsia dianalisis secara statistik menggunakan software SPSS.

\section{Hasil}

\section{Karakteristik Sampel}

Penelitian ini dilaksanakan pada 50 subjek penelitian, yang terdiri dari 25 ibu hamil dengan normal (kelompok kontrol) dan 25 ibu hamil dengan preeklampsia (kelompok kasus). Pada Tabel 1 ditunjukkan karakteristik sampel penelitian berdasarkan usia kehamilan yaitu early onset (usia kehamilan kurang dari dan sama dengan 34 minggu) dan late onset (usia kehamilan lebih dari 34 minggu). Pada kelompok kontrol, usia ibu hamil early onset tidak memiliki perbedaan yang bermakna dengan ibu hamil late onset ( $p=0,288$ ). Demikian pula dengan kelompok kasus yang menunjukkan tidak ada perbedaan yang signifikan rerata usia ibu hamil pada kedua kelompok tersebut $(p=0,921)$.

Tabel 1 Karakteristik sampel penelitian berdasarkan usia kehamilan

\begin{tabular}{|c|c|c|c|c|c|c|}
\hline \multirow[b]{2}{*}{ Karakteristik sampel } & \multicolumn{2}{|c|}{$\begin{array}{l}\text { Normal } \\
(n=25)\end{array}$} & \multirow[b]{2}{*}{$p$-value } & \multicolumn{2}{|c|}{$\begin{array}{c}\text { Preeklampsia } \\
(\mathrm{n}=25)\end{array}$} & \multirow[b]{2}{*}{$p$-value } \\
\hline & $\begin{array}{l}\text { Early } \\
\text { Onset } \\
(\mathrm{n}=5)\end{array}$ & $\begin{array}{c}\text { Late } \\
\text { Onset } \\
(n=20)\end{array}$ & & $\begin{array}{l}\text { Early } \\
\text { Onset } \\
(\mathrm{n}=5)\end{array}$ & $\begin{array}{c}\text { Late } \\
\text { Onset } \\
(\mathrm{n}=20)\end{array}$ & \\
\hline Usia (tahun) & 2,60 & 27,85 & $0,288)^{a}$ & 28,50 & 28,11 & $\overline{0,921)^{\mathrm{a}}}$ \\
\hline \multicolumn{7}{|l|}{ Tekanan darah } \\
\hline Sistol & 110,00 & 111,50 & $0,688)^{a}$ & 170,00 & 162,63 & $0,069)^{c}$ \\
\hline Diastol & 70,00 & 73,00 & $0,418)^{a}$ & 98,33 & 93,68 & $0,198)^{c}$ \\
\hline \multicolumn{7}{|l|}{ Cara lahir } \\
\hline SC & 3 & 8 & & 3 & 5 & \\
\hline Spontan & 2 & 12 & & 2 & 15 & \\
\hline Usia kehamilan (minggu) & 32,00 & 38,35 & $0,000)^{b}$ & 32,33 & 38,53 & $0,000)^{b}$ \\
\hline Berat badan lahir (gram) & 2532,00 & 3176,60 & $0,004)^{b}$ & 2710,00 & 2621,11 & $0,788)^{a}$ \\
\hline
\end{tabular}

Keterangan: a) tidak ada perbedaan yang bermakna pada uji $t$, b) ada perbedaan yang bermakna pada uji $t$, c) tidak ada perbedaan yang bermakna pada uji Mann-Whitney 
Kemudian, didapatkan nilai tekanan darah sistol dan diastol tidak ada perbedaan yang bermaka antara kelompok usia kehamilan early onset dengan kelompok usia kehamilan late onset (berturut-turut nilai $p=$ 0,688 dan $p=0,418$ ). Demikian pula dengan kelompok kasus yang menunjukkan tidak ada perbedaan yang bermakna tekanan darah sistol dan diastol pada kedua kelompok (berturut-turut nilai $p=0,069$ dan $p=0,198$ ).

Pada kelompok kontrol, diketahui usia kehamilan early onset berbeda secara signifikan dengan kelompok usia kehamilan late onset $(p=0,000)$. Demikian juga pada kelompok kasus diketahui usia kehamilan early onset berbeda signifikan dengan usia kehamilan late onset $(p=0,000)$.

Selain itu, pada kelompok kontrol diketahui berat badan lahir (BBL) pada kelompok early onset berbeda secara signifikan dengan kelompok late onset $(\mathrm{p}=$ 0,004). Akan tetapi, pada kelompok kasus diketahui berat badan lahir (BBL) kelompok early onset tidak berbeda bermakna dibandingkan dengan kelompok late onset ( $p$ $=0,788$ ).

Amplifikasi Gen STOX1 pada Kelompok Kontrol dan Kelompok Kasus

Pada penelitian ini didapatkan DNA total dari darah vena ibu hamil normal dan ibu hamil preeklamsia yang memiliki konsentrasi yang adekuat di atas konsentrasi DNA minimal, yakni $50 \mathrm{ng} / \mu \mathrm{l}$. Selanjutnya dari DNA total tersebut dilakukan amplifikasi gen STOX1 dengan PCR dan didapatkan produk PCR berupa pita DNA sebesar 639 bp pada kelompok normal (Gambar 1) dan kelompok kasus (Gambar 2).

\section{Polimorfisme Varian T-344C Gen STOX-1 pada Kelompok Normal}

Penentuan region yang akan dipotong dengan enzim restriksi Haelll pada varian T344C gen STOX-1 mengikuti sekuens referensi NCBI: NG_008374.1 (Gambar 3). Daerah yang akan dipotong dengan enzim Haell adalah daerah yang memiliki pola restriksi GGCC. Titik potong tersebut dapat bersifat terpotong satu titik pada posisi 402 bp atau normal (TT), heterozigot(TC) atau terpotong pada dua titik potong yakni pada posisi 402 bp dan 334 bp, dan homozigot (CC) atau terpotong pada satu titik potong di posisi 334 bp. Pada Gambar 4 dapat diketahui profil potongan DNA varian T-344C gen STOX-1 pada kelompok kontrol. Pada kelompok kontrol didapatkan frekuensi TT pada varian $\mathrm{T}-344 \mathrm{C}$ memiliki persentase tertinggi yaitu $64 \%$, lalu TC dan CC yang masing-masing sebesar 28\% dan 8\% (Tabel 2).

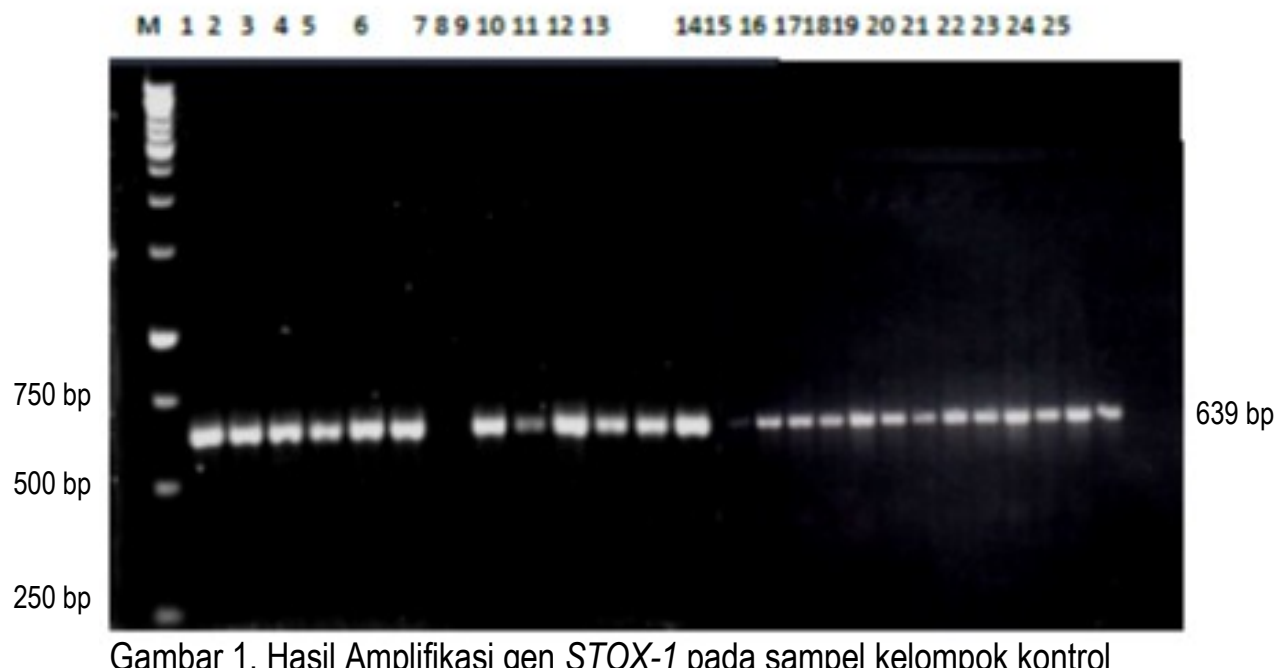

Keterangan : M: Marker100 bp DNA ladder (Fermentas, USA); 1- 25 : produk PCR kelompok kontrol (639 bp) 


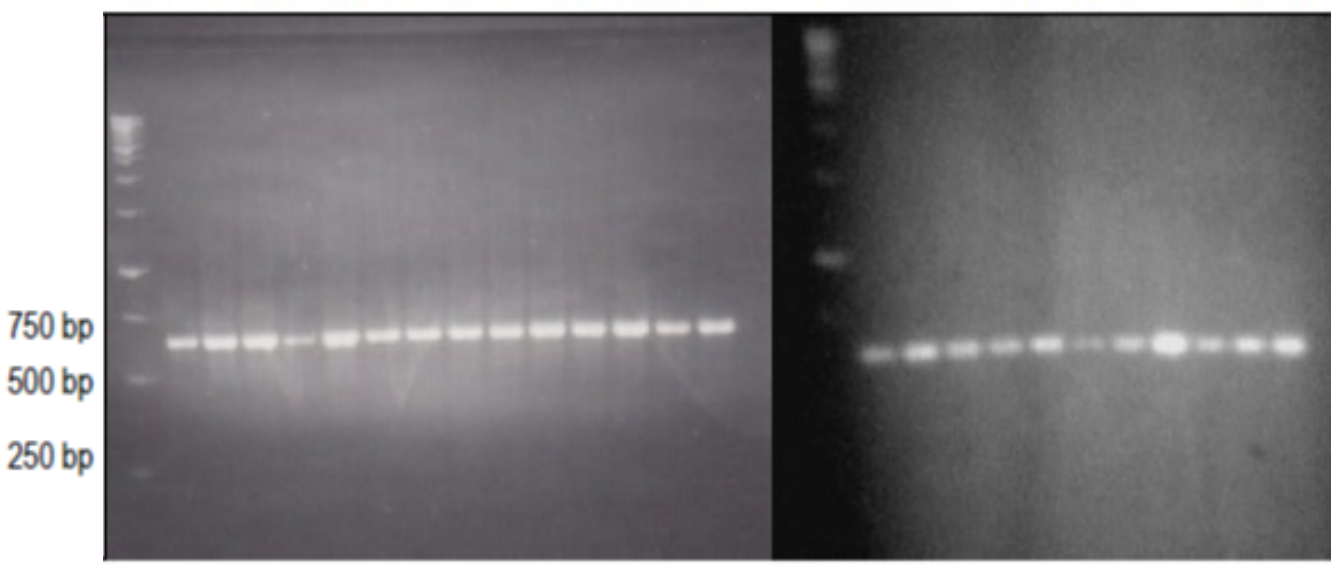

Gambar 2. Hasil Amplifikasi gen STOX-1 pada kelompok kasus

Keterangan : M: Marker 100 bp DNA ladder (Fermentas, USA); 1- 25 : produk PCR kelompok kasus (639 bp)

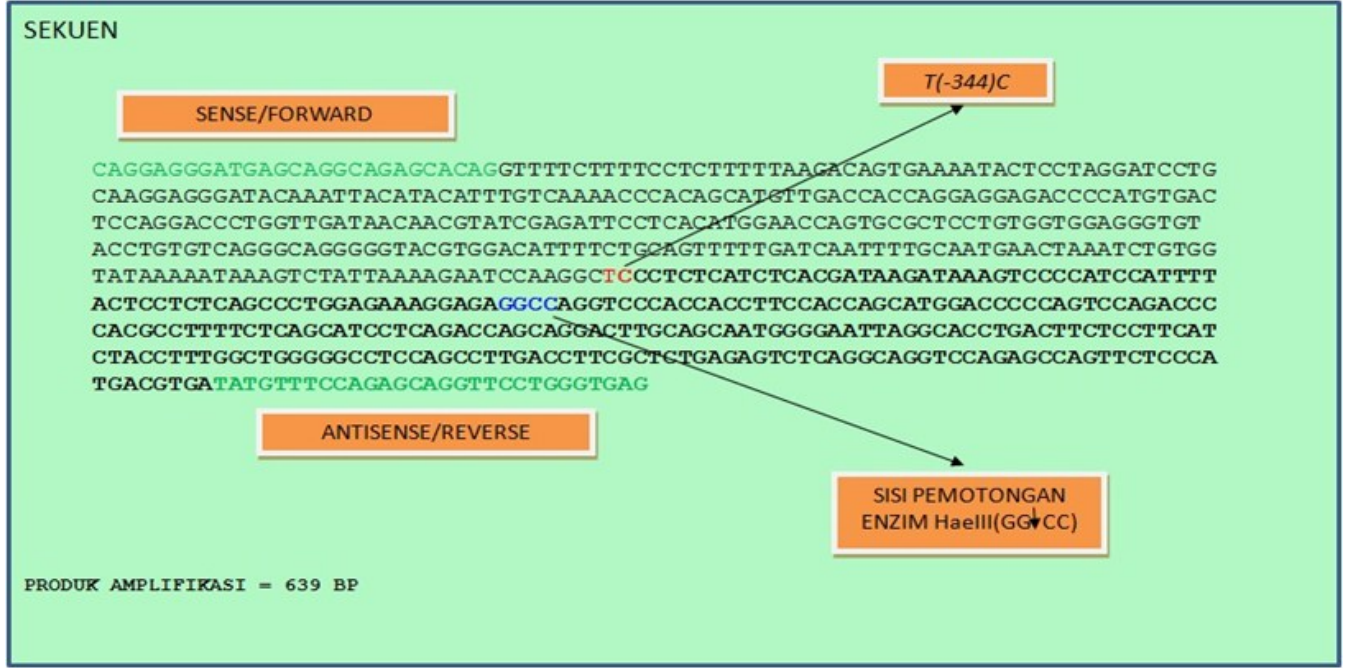

Gambar 3. Sekuen varian T-344C gen STOX-1 dengan posisi titik potong enzim restriksi Haelll berdasarkan sekuens referensi NCBI: NG_008374.1

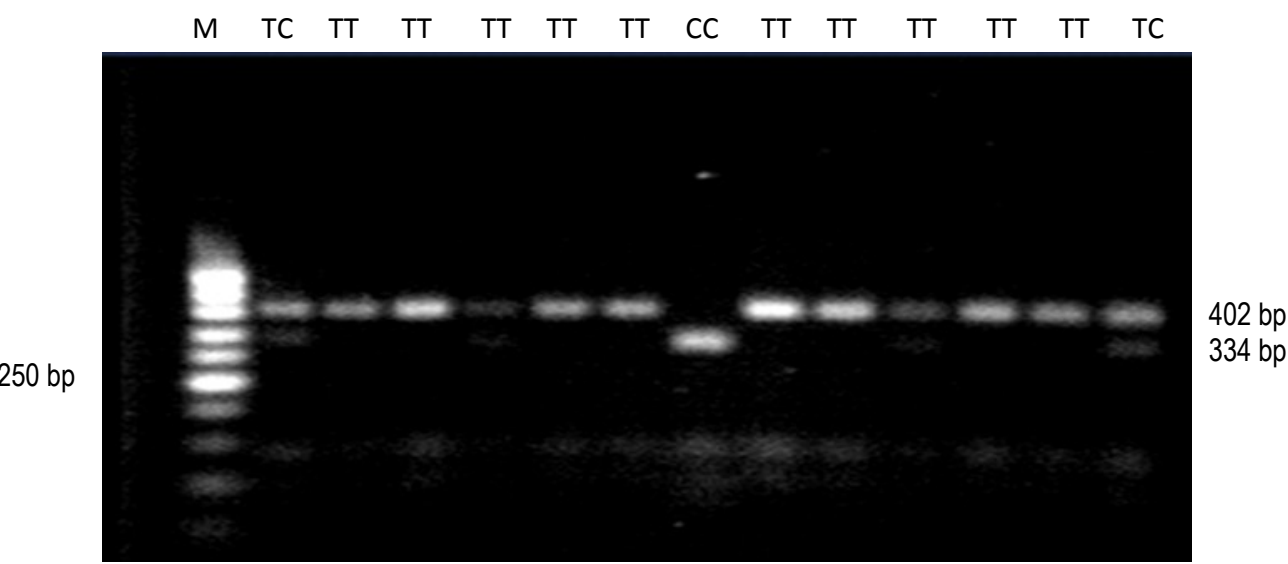

Gambar 4. Profil RLFP varian T-344C gen STOX-1 dengan enzim Haelll pada kelompok kontrol

Keterangan: M: Marker DNA ladder 250 bp; TT: Sampel terdeteksi pada posisi 402 bp; TC: Sampel terdeteksi pada posisi 402 bp dan 334 bp; CC: Sampel terdeteksi pada posisi 334 bp 
Tabel 2. Frekuensi genotip varian T-344C gen STOX-1 pada kelompok kontrol

\begin{tabular}{lc}
\hline Genotip Varian T-344C & \% Frekuensi (n) \\
\hline TT & $64 \%(16)$ \\
TC & $28 \%(7)$ \\
CC & $8 \%(2)$ \\
Total & $100 \%(25)$ \\
\hline
\end{tabular}

Polimorfisme Varian T-344C Gen STOX-1 pada Kelompok Kasus

Profil potongan DNA varian T-344C gen STOX-1 dengan RFLP pada kelompok kasus ditemukan 2 jenis genotip, yakni normal (TT) dan heterozigot (TC). Akan tetapi tidak ditemukan genotip homozigot (CC) (Gambar 5). Pada kelompok kasus didapatkan dua genotip varian T-344C yaitu TT dengan frekuensi sebesar $72 \%$ dan TC sebesar $28 \%$ (Tabel 3).
Uj Korelasi antara Polimorfisme Varian T344C Gen STOX-1 dengan Preeklaamsia

Untuk mengetahui apakah antara varian T-344C gen STOX1 berhubungan dengan preeklamsia, maka dilakukan uji Mann Whitney dan didapatkan nilai $p=0,668>$ 0,05 , yang berarti tidak ada hubungan antara polimorfisme varian T-344C gen STOX1 yang teramati pada kelompok kasus dan kelompok normal dengan status preeklamsia subjek penelitian.

M TT TT TC TC TC TT TC TT TT - TT TT TC TT

$250 \mathrm{bp}$

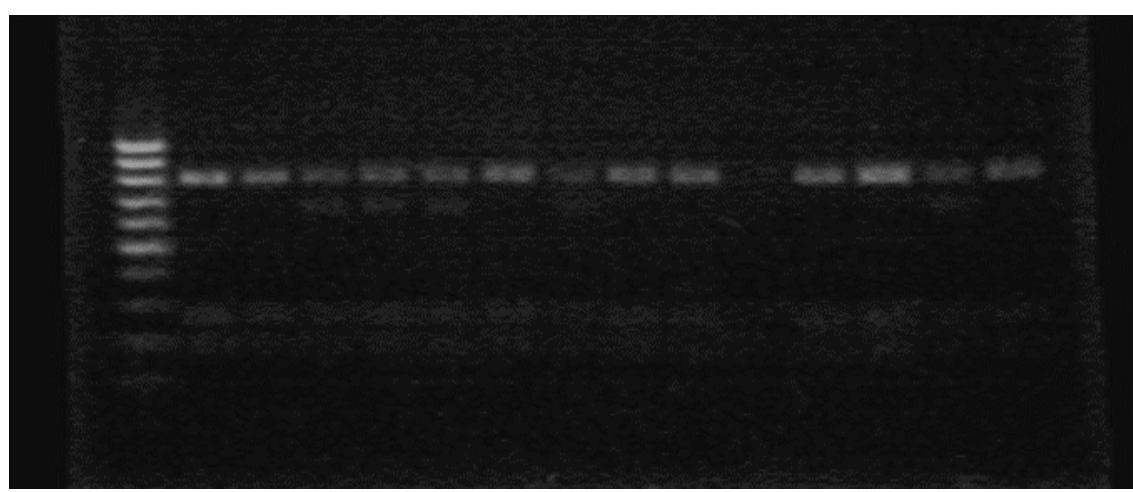

Gambar 5. Profil RLFP varian T-344C gen STOX-1 dengan enzim Haelll pada kelompok kasus Keterangan: M: Marker DNA ladder 250 bp; TT: Sampel terdeteksi pada posisi 402 bp; TC: Sampel terdeteksi pada posisi 402 bp dan 334 bp; CC: Sampel terdeteksi pada posisi 334 bp

Tabel 3. Frekuensi genotip varian T-344C gen STOX-1 pada kelompok kasus

\begin{tabular}{lc}
\hline Genotip Varian T-344C & \% Frekuensi (n) \\
\hline TT & $72 \%(18)$ \\
TC & $28 \%(7)$ \\
CC & $0 \%(0)$ \\
Total & $100 \%(25)$ \\
\hline
\end{tabular}




\section{Pembahasan}

Preeklampsia adalah suatu kelainan vaskular yang spesifik dialami ibu hamil. Manifestasi klinik preeklampsia baru muncul setelah 20 minggu kehamilan, walaupun proses patofisiologisnya terjadi sejak awal perkembangan plasenta. ${ }^{15}$ Faktor risiko utama wanita menderita preeklampsia adalah nulliparitas. Menurut penelitian metaanalisis dilaporkan bahwa wanita yang hamil pertama kalinya memiliki kemungkinan hampir 3 kali menderita preeklampsia dibandingkan kehamilan kedua dan seterusnya. ${ }^{16}$ Umur juga merupakan faktor risiko penting terjadinya preeklampsia pada wanita dengan usia $\geq 40$ tahun memiliki kemungkinan dua kali lebih besar dibanding wanita usia $\leq 40$ tahun. ${ }^{16}$ Meskipun pada penelitian ini faktor umur diketahui tidak menunjukkan perbedaan yang bermakna pada kedua kelompok (Tabel 1).

Beberapa penelitian terakhir berusaha mengaitkan antara kejadian preeklampsia dengan polimorfisme gen STOX1 pada kromosom 10q22 pada populasi di Belanda dan Finlandia melalui pendekatan genetic linkage analysis. Walaupun hasilnya menunjukkan bahwa gen STOX1 belum dapat divalidasi sebagai a common preeclampsia susceptibility gene. ${ }^{17}$

Berbeda dengan penelitian sebelumnya, pada penelitian ini menunjukkan bahwa secara teknis pemeriksaan varian T-344C gen STOX1 dapat digunakan sebagai kandidat biomarker pemeriksaan molekuler preeklamsia. Hasil penelitian menunjukkan adanya polimorfisme varian T-344C (TT,TC, dan CC) gen STOX1 dengan pemotongan menggunakan enzim restriksi Haelll pada kelompok kontrol dan kasus. Namun, secara spesifik varian T-344C gen STOX1 tidak dapat digunakan untuk menjelaskan adanya fenomena alel homozigot pada kelompok kontrol (CC).
Penelitian Kivinen et al. (2007) mendukung hasil penelitian ini melalui analisis mutasi pada gen STOX1 yang menyebabkan terjadinya overekspresi gen STOX1 sehingga menghasilkan profil transkripsi berlebihan. Akibat overekspresi gen STOX1, maka invasi trofoblas menjadi terhambat untuk membentuk penonjolan trofoblas ekstravili pada trimester pertama. Hambatan pembentukan tonjolan trofoblast ekstravilli ini diperkirakan dimediasi oleh regulasi $\alpha-T-c a t e n i n$ yaitu protein yang terlibat dalam adhesi sel-sel yang diregulasi pada kejadian preeklamsia. ${ }^{17,18}$

Pada penelitian ini didapatkan frekuensi polimorfisme TT (normal) pada varian T-344C memiliki persentase tertinggi yakni sebesar $64 \%$ pada kelompok kontrol dan $72 \%$ pada kelompok kasus. Kemudian didapatkan frekuensi TC sebesar 28\% pada kelompok kontrol maupun kelompok kasus dan CC sebesar $8 \%$ hanya pada kelompok kontrol. Adanya temuan genotip CC pada kelompok normal sejalan dengan hasil penelitian Kim et al. (2009) bahwa mutasi homozigot $(\mathrm{HH})$ varian $\mathrm{Y} 153 \mathrm{H}$ gen STOX1 pada kontrol penelitian tidak berhubungan dengan preeklampsia pada populasi Korea, meskipun menurut Mrozikiewicz et al. (2008) seharusnya mutasi pada gen STOX1 terlibat dalam kerentanan terhadap preeklampsia. ${ }^{19,20}$ Identifikasi gen kerentanan untuk preeklampsia telah terbukti lebih sulit dilakukan. Hal ini disebabkan bahwa genetika preeklampsia memiliki karakterisasi penyakit yang kompleks, yang melibatkan beberapa efek genetik (efek interaktif lebih dari satu gen)..21 Menurut Marie et al. (2011), selain gen STOX1 ada beberapa gen lain seperti gen ACVR2A atau CYP11B2, yang memberikan kerentanan untuk preeklampsia. ${ }^{22}$ Penelitian Procopciuc et al. (2010) menunjukkan bahwa polimorfisme genotip T-344C gen CYP11B2 berkontribusi pada risiko preeklamsia sebesar $1,29(95 \% \mathrm{Cl}$ $[0,59-2.79], p=0,53) .23$ 
Oleh karena itu, polimorfisme genotip (CC) gen STOX1 saja tidak dapat dijadikan sebagai satu-satunya acuan terhadap kerentanan terhadap preeklampsia.

Meskipun penelitian ini menemukan adanya polimorfisme varian T-344C gen STOX1, namun hal ini tidak berhubungan secara bermakna dengan preeklamsia $(p=$ $0,668>0,05)$. Hasil ini sejalan dengan penelitian George et al. (2013) pada populasi Finlandia dan Kim et al. (2009) pada populasi Korea bahwa tidak ditemukannya korelasi antara polimorfisme gen STOX1 dengan preeklampsia karena selain faktor gen juga dipengaruhi oleh faktor plasenta dan ibu beserta kombinasinya. $18,19 \mathrm{Hal}$ ini berdampak pada keparahan penyakit, waktu onset, dan terjadinya komplikasi tambahan misalnya Intra Uterine Growth Restriction (IUGR) pada penderita preeklampsia. Oleh karena itu, diperlukan idenifikasi gen lain pada populasi yang berbeda, agar didapatkan pemahaman yang lengkap tentang preeklamsia. Hal ini karena gen STOX1 merupakan faktor transkripsi yang mengatur banyak gen sehingga perlu identifikasi genomik lebih lanjut. Dengan mengidentifikasi gen lain yang terlibat dengan preeklamsia, maka keberhasilan studi fungsional pada gen yang terkait dengan preeklamsia akan sesuai dengan yang diharapkan, tanpa harus fokus hanya pada satu gen..$^{22}$

\section{Kesimpulan}

Kesimpulan penelitian ini adalah bahwa polimorfisme varian T-344C gen STOX1 dapat digunakan sebagai kandidat biomarker molekuler pada pasien preeklampsia melaui perbedaan profil genotip (TT,TC, dan CC) dengan pemotongan gen STOX1 menggunakan enzim restriksi Haelll. Namun, tidak spesifik untuk menjelaskan hubungan antara polimorfisme gen STOX1 dengan kejadian preeklampsia.

\section{Saran}

Perlu dilakukan penelitian lebih lanjut untuk menentukan sensitifitas varian T-344C gen STOX1 pada sampel penelitian yang lebih besar untuk mendapat gambaran peran STOX1 pada preeklamsia secara yang lebih akurat.

\section{Daftar Pustaka}

1. Hogberg U. Genome-Wide Aociation Studuies for Common Disease and Complex Traits. Nat Rev Genet. 2005; 6:95-108.

2. Roberts JM and Hubel CA The Two Stage Model of Preeclampsia: Variations on the Theme. Placenta. 2009; 30 Suppl A:S3237.

3. Cnatingius S, Reilly M, Pawitan $Y$ and Lichtenstein P. Maternal and Fetal Genetic Factors Account for Most of Familial Aggregation of Preeclampsia : a Population-Based Swedish Cohort Study. Am J Med Genet. 2004; A 130A:365-371.

4. Duley L. Pre-Eclampsia and the Hypertensive Disorder of Pregnancy. $\mathrm{Br}$ Med Bull. 2003; 67:25, 115-121.

5. Lachmeijer AM, Arngrimsson R, Bastiaans EJ, Frigge ML et al. A Genome-Wide Scan for Preeclampsia in the Netherlands. Eur $J$ Hum Gene. 2001; 9:758-764.

6. Laivuori $H$, Lahermo $P$, Ollikainen $V$, Widen $E$ et al. Suspectibility Loci for Preeclampsia on Chromosome 2p25 and $9 p 13$ in Finnish Families. Am J Hum Genet. 2003; 72:168-177.

7. van Dijk, Mulders J, Poutsma A, Konst AA et al. Maternal Segregation of the Dutch Preeclampsia Locus at 10q22 with a New Member of the Winged Helix Gene Familiy. Nat Genet. 2005; 37:514-519. 
8. Oudejans CB, Mulders J, Lchmeijer Am, van Djik $M$ et al. The Parent-of-Origin Effect of 10q22 in Pre-Eclamptic Females Coincides with Two Regions Clustered for Genes with DownRegulated Expression in Androgenetic Placentas. Mol Hum Reprod. 2004; 10:589-598.

9. Iglesias-Platas I, Monk D, Jebbink J, Buimer $\mathrm{M}$ et al. STOX1 is Not Imprinted and is not Likely to be Involved in Preeclampsia. Nat Genet. 2007; 39:279280

10. Rigourd V, Chauvet C, Chelbi ST, Rebourcet $R$ et al. STOX1 Overexpression in Choriocarcinoma Cells Mimics Transcriptional Alterations Obeserved in Preeclamptic Placentas. PloS One. 2008; 3:e3905.

11. Founds SA, Conley YP, Lyons-Weiler $J F$, Jeyabalan A et al. Altered Global Gene Expression in First Trimester Placentas of Women Destined to Develop Preeclampsia. Placenta. 2009; 30:15-25.

12. Devendran A, Nampoothiri S, Shewade DG, Chatterjee S, Jayaraman B, Chandrasekharan A. Allele, Genotype and Haplotype Structures of Functional Polymorphic Variants in Endothelial Nitric Oxide Synthase (eNOS), Angiotensinogen (ACE) and Aldosterone Synthase (CYP11B2) Genes in Healthy Pregnant Women of Indian Ethnicity. J Reprod Infertil. 2015;16(4):180-192.

13. Tu Y, Cui G, Xu Y, Bao X, Wang X, Wang DW. Genetic Polymorphism of CYP11B2 Gene and Stroke in the Han Chinese Population and a Metaanalysis. Pharmacogenet Genomics. 2011; 21 (3):115-20

14. Hofmeyr GJ, Duley L and Atallah A Dietary Calcium Supplementation for Prevention of Preeclampsia and Related
Probelms: a Systematic Review and Commentary. Bjog. 2007; 114: 933-943.

15. Steegers EAP, von Dadelszen, Duvekot JJ, and Pijnenborg R. Preeclampsia. The Lancet. 2010; 376(9741):631-644.

16. Duckitt $\mathrm{K}$ and Harrington D. Risk Factors for Preeclampsia at Anternatal Booking: Systematic Review of Controlled Studies. BMJ. 2005; 330:565.

17. Kivinen K, Peterson H, Hiltunen L, Laivuori $\mathrm{H}$, Heino S, Tiala I, Knuutila S, Rasi V, Kere J. Evaluation of STOX1 as a Preeclampsia Candidate Gene in a Population-Wide Sample. Eur J Hum Genet. 2007; 15(4):494-7.

18. George EM and Bidwell GL. STOX1: a New Player in Preeclampsia?. Greenville Avenue, Dallas: American Heart Association, Inc. 2013.

19. Kim SY, Park SY, Lim JH, Yang JH, Kim MY, Park HY, Lee KS, Kim YJ, Ryu HM. The Y153H Variant of the STOX1 Gene in Korean Patients with Preeclampsia. $J$ Genet Med. 2009; 6:56-61.

20. Agnieszka Seremak-Mrozikiewicz, Genetics of Preeclampsia - Current Concepts. Archives of Perinatal Medicine. 2008; 14(4):9-11.

21. Roten LT. Genetic Predisposition for Development of Preeclampsia Candidate Gene Studies in the HUNT (NordTrøndelag Health Study) Population. Thesis. Department of Cancer Research and Molecular Medicine: Norwegian University of Science and Technology. 2009. P.157.

22. van Dijk M, Cees B, and Oude JM, STOX1: Key Player in Trophoblast Dysfunction Underlying Early Onset Preeclampsia with Growth Retardation. Journal of Pregnancy. 2011; 2011: Article ID 521826. 7 pages. doi:10.1155/2011/521826. 
23. Procopciuc L, Caracostea G, Puscas M, lordache $G$, Olteanu I, Stamatian F. The T344c-CYP11B2 Polymorphism as A Risk Factor for Preeclampsia in Romanian Pregnant Women. Association With M235t (AGT) And I/D (ACE) Polymorphisms. Journal of Hypertension. 2010; 28:e-Supplement A. 